agreed findings of the report of the Royal Commission on the Geographical Distribution of the Industrial Population are substantially consistent with evidence given before the Commission by the Association and have proved of the utmost value as a basis for national policy. The Council is considering what forms of activity are practicable in present circumstances to use the new opportunities. The formation of groups, in as many towns as possible, which will undertake research and education in the local application of a national planning policy, is desirable. There is a great demand from men in the services and civilian groups for well-informed talks and booklets on future planning. Much also needs to be done to develop sound policy and technical knowledge among members of local authorities and their staffs. The report also directs attention to the change in name of the Association from "The Garden Cities and Town Planning Association", and includes a short statement of town-country planning principles, adopted by the Council in January 1941, acceptance of which by the Government and Parliament is urged.

These suggestions include the establishment of a Ministry, advised by a National Planning Council, to guide future development and re-development, and the future grouping of industry and population, to secure the best use of the land and to conserve the national resources in the general interest. The distinction between town and county should be maintained in all development, and sporadic building in rural areas discouraged. In particular, good foodgrowing land, places of special landscape beauty, and areas suitable for national parks or coastal reservations should be protected from ordinary building development. Good design and lay-out of buildings and roads as well as sound construction should be an object of policy. In rebuilding urban areas, the density of residential districts should be limited to provide sufficient open space, including reasonable garden space, and wide country belts should be reserved around all cities and towns. New develop. ments required by industrial changes, decentralization from congested areas, or by the growth of towns up to their planned limits should be directed to other towns or to new towns carefully sited and planned. The Ministry charged with national planning should have power to prevent, except under licence, the settlement of new industrial undertakings in overgrown or congested towns and in undeveloped rural areas, and to offer inducements to industry to settle in suitably selected places. The inadequate provisions for compensation and betterment under the Town $\varepsilon$ nd Country Planning Act should be replaced by new legislation based on expert consideration before the conclusion of the War.

\section{Soil Mechanics in Brazil}

Among the papers contributed to the Third Reunion of the Brazilian National Laboratories for Testing Materials was one on soil stabilization, which has since been issued as a booklet by the National Institute of Technology, Rio de Janeiro. The author, Paulo Sá, outlines existing knowledge in this branch of the science of soil mechanics, in the hope of directing the attention of Brazilian engineers to this new and important science. This would be a commendable aspiration in any country. Too many engineers are unfamiliar with the extent to which the study of foundation and earthwork problems has been developed during the last ten or twenty years, for it is now legitimate to speak of the emergence of a rational science of soil mechanics, based on sound scientific principles and making full use of theory, experiment and practice. Here again, as in most cases of fresh scientific approach to an old problem, research has established a considerable lead on practical application. The Brazilian writer complains that, in his country, soil mechanics specialists are muito poucos: in Great Britain also they are all too few. But the subject is not only a matter for the specialist. It should become part of the training of all civil engineers. Emphasis has been laid on the need for greater attention to it in Great Britain in annual reports of the Building Research Board which, in its report for 1938, noted with satisfaction steps taken at several university institutions, following a conference at the Building Research Station, to bring the subject into greater prominence in the curriculum for enginorring students.

\section{Electric Heating in the Pottery Industry}

THE new pottery factory of Messrs. Josiah Wedgwood and Sons, Ltd., at Barlaston, has been described in articles in the Electric Review of April 18 and May 2. For the first time in Great Britain, electrical biscuit and glost firing have been combined in one kiln. In biscuit firing the pottery is subjected to direct radiation from the source of heat instead of being stacked in the kiln in special containers (saggars). Both the biscuit and glost firing are effected in a double tunnel kiln of the conveyor type. The two tunnels-one biscuit and one glost-are side by side, so as to reduce construction costs and effect a measure of heat recuperation. In each tunnel there are a heating-up and a cooling-down section at opposite ends of the firing zone, and the sequence in the case of biscuit firing is opposite to that of glost firing. The overall length of the kiln is $272 \mathrm{ft}$. and the firing zone is about $100 \mathrm{ft}$. long. Each tunnel measures about $6 \mathrm{ft}$. by $4 \mathrm{ft}$. inside, just a little larger than the trucks which convey the wares through the kiln. The firing zone of each tunnel has a number of sections, the temperatures of which, as recorded by pyrometers on the outside walls and at the centres of the sections, follow a desired curve in each case, with a maximum in the case of biscuit firing of about $1,150^{\circ} \mathrm{C}$. 'Kanthal' type or aluminium-iron elements consisting of strip about $\frac{1}{2}$ in. wide wound spirally on a refractory former atout $3 \mathrm{ft}$. long are used. Trucks carrying the pottery run on rails continuously through the kiln end to end as a train, the whole being propelled by a pusher unit, which operates with the end truck at the tunnel entrance. Enamelling firing for colour work demands a temperature of about $850^{\circ} \mathrm{C}$., which 